JURNAL MAKSIPRENEUR, Vol. VI, No. 2, Juni 2017, hal. 65 - 76

\title{
ANALISIS KINERJA PEGAWAI GUNA MENUNJANG KINERJA ORGANISASI DALAM MEMBERIKAN PELAYANAN MASYARAKAT
}

\author{
Siti Noor Hidayati \\ Fakultas Ekonomi Universitas Proklamasi 45 Yogyakarta \\ Syamyudi \\ UPTD PKB Dishubkominfo Pemkab Sleman
}

Korespondensi penulis: datik_ng@yahoo.com

\begin{abstract}
Employee of UPTD PKB Dinas Perhubkominfo Kabupaten Sleman in providing services of motor vehicle testing must meet the criteria as contained in the SK MENPAN No.63/2003 covering six criterias that are service procedure, service time, service cost, service product, infrastructure, and competence of service provider. Consumer satisfaction of the application of motor vehicles testing measured with five characteristics, that are tangibles, reliability, responsiveness, assurance, and empathy. The results of this research indicate that performance of employee in service will support organizational performance significanly (Z-test). The variables of organizational performance (service procedure, service time, service cost, service product, infrastructure, and competence of service provider) have an effect to increase consumer satisfaction of the application of motor vehicles test, partially ( $t$-test) and also simultaneously ( $F$-test). In this research, the dominant effect of customer satisfaction to organizational performance is infrastructure.
\end{abstract}

Keywords: employee performance, organizational performance, customer satisfaction.

\section{PENDAHULUAN}

Sumber daya manusia (SDM) di dalam suatu organisasi atau perusahaan merupakan komponen yang esensial untuk menjalankan roda organisasi atau perusahaan atau lembaga untuk mencapai tujuannya. Pada umumnya, kehidupan di dalam organisasi, apa pun bentuk dan sifatnya, baik yang bergerak di bidang perdagangan maupun bidang jasa, akan selalu berusaha mencapai tujuan yang telah ditetapkan sebelumnya secara efektif dan efisien. Karyawan atau pegawai atau pekerja atau buruh adalah makhluk sosial yang menjadi kekayaan utama bagi setiap organisasi. Pekerja adalah setiap orang yang bekerja dengan menerima upah atau imbalan dalam bentuk lain (UU RI No. 13 Tahun 2003 tentang Ketenagakerjaan). Pegawai menjadi pelaku yang menunjang tercapainya tujuan organisasi, mempunyai pikiran, perasaan, dan keinginan yang dapat mempengaruhi sikap-sikapnya terhadap pekerjaan. Keberhasilan suatu perusahaan sangat dipengaruhi oleh kinerja individu karyawan. Setiap perusahaan akan selalu berusaha untuk mendapatkan kinerja terbaik karyawan, dengan harapan apa yang menjadi tujuan perusahaan akan tercapai.

Pegawai Negeri Sipil (PNS) merupakan aset pemerintah yang sangat berharga yang harus dikelola dengan baik oleh pemerintah agar dapat memberikan kontribusi yang 
optimal. Pemerintah bukan hanya sebagai abdi negara saja, tetapi juga sebagai abdi masyarakat yang mengayomi dan memberikan pelayanan kepada masyarakat dengan sebaik-baiknya. PNS merupakan salah satu sumber daya manusia yang dimiliki oleh pemerintah dalam menjalankan tugas-tugas pemerintahan (UU No. 25 Tahun 2009). Salah satu hal yang menjadi perhatian utama pemerintah mengenai sumber daya manusianya adalah kinerja pelayanan yang diberikan kepada masyarakat. Mangkunegara (2005) mengemukakan bahwa kinerja adalah hasil kerja secara kualitas dan kuantitas yang dicapai oleh seorang pegawai dalam melaksanakan tugasnya sesuai dengan tanggung jawab yang diberikan kepadanya, sedangkan kinerja menurut Hasibuan (2012) adalah suatu hasil kerja yang dicapai seseorang dalam melaksanakan tugas-tugasnya atas kecakapan, usaha, dan kesempatan. Berdasarkan paparan tersebut di atas, kinerja adalah suatu hasil yang dicapai seseorang dalam melaksanakan tugas-tugas yang didasarkan atas kecakapan, pengalaman, dan kesungguhan serta waktu menurut standar dan kriteria yang telah ditetapkan sebelumnya.

Kinerja pegawai dan organisasi merupakan kinerja yang dilakukan untuk memberikan pelayanan kepada konsumen. Pelayanan merupakan segala bentuk layanan yang diberikan pada dasarnya bertujuan untuk memenuhi kepentingan umum atau kepentingan perorangan yang bertumpu pada hak dasar sebagai warga negara. Bentuk layanan di Indonesia adalah (Moenir, 2002): (1) Layanan dengan lisan, (2) Layanan melalui tulisan, dan (3) Layanan dalam bentuk perbuatan. Pada umumnya, layanan dalam bentuk perbuatan $70-80 \%$ dilakukan oleh petugas-petugas tingkat menengah dan bawah, karena faktor keahlian dan ketrampilan petugas sangat menentukan hasil perbuatan pekerjaan. Salah satu sumber daya manusia di pemerintahan adalah pegawai UPTD Pengujian Kendaraan Bermotor (PKB) Dinas Perhubungan, Komunikasi, dan Informatika Kabupaten Sleman dalam memberikan pelayanan Pengujian Kendaraan Bermotor (PKB). Saat ini, kendaraan bermotor menjadi salah satu kebutuhan pokok masyarakat dalam menjalankan aktivitas sehari-hari untuk memenuhi kebutuhan manusia. Agar aman dan layak untuk digunakan, maka perlu dilakukan pengujian demi keselamatan pengemudi maupun pengendara lain. Maraknya kecelakaan kendaraan umum belakangan ini membuat seluruh PKB menjadi sorotan.

PKB adalah serangkaian kegiatan pengujian yang memeriksa bagian-bagian kendaraan bermotor, kereta gandengan, kereta tempelan, dan kendaraan khusus dalam rangka pemenuhan terhadap persyaratan teknis dan layak jalan. Tujuan penyelenggaraan PKB yaitu untuk memberikan kepastian bahwa kendaraan bermotor yang dioperasikan di jalan telah memenuhi persyaratan teknis dan layak jalan, serta tidak mencemari lingkungan. PKB diperlukan agar tercipta transportasi darat yang sesuai dengan kelayakan untuk berada di jalan dan juga agar pelanggan transportasi darat merasa aman, nyaman, cepat atau lancar, dan tertib atau teratur, serta lebih percaya pada sarana transportasi yang digunakan, termasuk kelengkapan surat-surat kendaraan bermotor yang merupakan kewenangan dari Dinas Perhubungan. Sasaran penyelenggaraan Pengujian Berkala Kendaraan Bermotor ditujukan kepada kendaraan wajib uji, yakni mobil penumpang umum, mobil bus, mobil barang, kereta tempelan, dan kereta gandengan.

Pengujian kendaraan dilakukan oleh Penguji Kendaraan Bermotor, yaitu PNS yang diberikan tugas, tanggung jawab, wewenang, dan hak secara penuh oleh pejabat yang berwenang untuk melakukan tugas pengujian kendaraan bermotor. Sebagai penguji kendaraan bermotor, pegawai tersebut harus memiliki Sertifikat Kompetensi dan Tanda Kualifikasi Teknis Penguji Kendaraan Bermotor. Pegawai dalam memberikan pelayanan harus memenuhi kriteria seperti yang tertuang dalam Surat Keputusan MENPAN No. 63/2003 tentang Pedoman Penyelenggaraan Umum yang pelayanannya meliputi: (1) 
prosedur pelayanan, (2) waktu pelayanan, (3) biaya pelayanan, (4) produk pelayanan, (5) sarana dan prasarana, serta (6) kompetensi petugas pemberi pelayanan. Dengan adanya pemenuhan standar pelayanan yang dimiliki pegawai tersebut maka organisasi yang dijalankannya juga dapat mencapai kinerja yang baik. Kinerja organisasi yang baik diharapkan dapat memberikan kepuasan kepada konsumen dalam pelayanannya.

Kinerja pegawai pemerintah dalam memberikan pelayanan sangat penting karena menjadi penilaian masyarakat mengenai citra pemerintah. Dengan kinerja pelayanan yang baik dari pegawai, maka masyarakat sebagai penerima layanan akan merasa puas sehingga citra pemerintah menjadi positif. Pelayanan dikatakan baik apabila dapat memenuhi kepuasan pihak-pihak yang menerima pelayanan, dan pelayanan yang diterima minimal sesuai harapannya. Tingkat kepuasan masyarakat menjadi tolok ukur terhadap kinerja pelayanan yang diberikan oleh pegawai. Menurut Kotler dan Keller (2009), kepuasan adalah perasaan senang atau kecewa seseorang yang timbul karena membandingkan kinerja yang dipersepsikan sebagai produk (atau hasil) terhadap ekspektasi mereka. Menurut Zeithaml dan Bitner (2000), definisi kepuasan adalah respon atau tanggapan konsumen mengenai pemenuhan kebutuhan. Kepuasan merupakan penilaian mengenai ciri atau keistimewaan produk atau jasa, atau produk itu sendiri, yang menyediakan tingkat kesenangan konsumen berkaitan dengan pemenuhan kebutuhan konsumsi konsumen. Berdasarkan beberapa pendapat di atas, kepuasan konsumen didefinisikan sebagai respon atau tanggapan konsumen baik senang atau kecewa mengenai pemenuhan kebutuhan yang menunjukkan pengalaman mengkonsumsi produk atau jasa.

Zeithaml, Berry, dan Parasuraman (dalam Yamit, 2005) mengemukakan bahwa dalam mengevaluasi dan mengukur kepuasan pelanggan terhadap pelayanan jasa terdapat lima dimensi karakteristik, yaitu:

(1) Bukti fisik atau penampilan (tangibles) merupakan kemampuan suatu institusi dalam menunjukkan eksistensinya kepada pihak eksternal. Penampilan dan kemampuan sarana prasarana fisik dan keadaan lingkungan sekitarnya adalah bukti nyata dan pelayanan yang diberikan oleh pemberi jasa. Bukti ini meliputi fasilitas fisik gedung, peralatan, penampilan petugas, dan kebersihan serta kenyamanan.

(2) Keandalan (reliability) merupakan kemampuan dari penyedia jasa untuk memberikan pelayanan secara cepat, akurat, dan dapat diandalkan. Kinerja harus sesuai dengan harapan konsumen yang berarti ketepatan waktu, pelayanan yang sama untuk semua konsumen, tanpa kesalahan, sikap yang simpatik dan akurasi yang tinggi.

(3) Responsif atau daya tangkap (responsiveness) merupakan kesediaan penyedia jasa terutama stafnya untuk membantu serta memberikan pelayanan yang tepat sesuai kebutuhan konsumen. Dimensi ini menekankan pada sikap dari penyedia jasa yang penuh perhatian, tepat, dan tanggap dalam pelayanan, yakni menghadapi permintaan, pertanyaan, keluhan, dan masalah konsumen dengan penyampaian informasi yang jelas.

(4) Keyakinan (assurance), dimensi ini menekankan kemampuan penyedia jasa untuk membangkitkan rasa percaya dan keyakinan diri konsumen bahwa pihak penyedia jasa terutama pegawainya mampu memenuhi kebutuhan konsumennya. Pegawai juga mampu melayani konsumen dengan yakin dan bebas dari keragu-raguan. Membiarkan konsumen menunggu tanpa adanya suatu alasan yang jelas menyebabkan persepsi yang negatif dalam kualitas pelayanan.

(5) Empati (emphaty) yaitu memberikan perhatian yang tulus dan bersifat individual yang diberikan kepada konsumen dengan berupaya memahami keinginannya. Dimensi ini merupakan kemampuan penyedia jasa dalam memperlakukan konsumen sebagai individu-individu yang spesial. 
Permasalahan dalam penelitian ini adalah bagaimana karakteristik responden pegawai UPTD PKB yang meliputi jenis kelamin, usia, pendidikan, masa kerja dan jenis pekerjan konsumen pemohon PKB Dinas Perhubkominfo Kabupaten Sleman? Seberapa tingkat pelayanan atau kinerja pegawai, kinerja organisasi, dan kepuasan konsumen UPTD PKB Dinas Perhubkominfo Kabupaten Sleman? Apakah kinerja pegawai menunjang kinerja organisasi. Atau apakah tidak ada perbedaan tingkat kinerja pegawai yang dinilai intern organisasi (UPTD PKB) dan kineja organisasi yang dinilai oleh konsumen (pemohon PKB), dalam pelayanan sesuai kriteria SK MENPAN No.63/2003? Apakah ada pengaruh kinerja organisasi (sesuai kriteria SK MENPAN No.63/2003 meliputi prosedur pelayanan, waktu pelayanan, biaya pelayanan, produk pelayanan, sarana dan prasarana, serta kompetensi petugas pemberi pelayanan) terhadap kepuasan konsumen pemohon PKB? Kriteria pelayanan mana yang memiliki pengaruh paling dominan terhadap kepuasan konsumen? Tujuan dalam penelitian ini adalah untuk menganalisis:

1. Mengidentifikasi karakteristik responden pegawai UPTD PKB dan responden pemohon PKB Dinas Perhubkominfo Kabupaten Sleman yang meliputi jenis kelamin, usia, dan pendidikan.

2. Mengidentifikasi tingkat pelayanan atau kinerja pegawai, kinerja organisasi dan kepuasan konsumen UPTD PKB Dinas Perhubkominfo Kabupaten Sleman.

3. Mengetahui perbedaan tingkat pelayanan atau kinerja pegawai yang dinilai intern organisasi (UPTD PKB) dan tingkat pelayanan atau kineja organisasi yang dinilai oleh konsumen (pemohon PKB), sesuai kiriteria SK MENPAN No.63/2003, yang berarti kinerja pegawai akan menunjang kinrerja organisasi.

4. Mengetahui pengaruh tingkat pelayanan atau kinerja organisasi (sesuai kiriteria SK MENPAN No.63/2003 meliputi prosedur pelayanan, waktu pelayanan, biaya pelayanan, produk pelayanan, sarana dan prasarana, serta kompetensi petugas pemberi pelayanan) terhadap kepuasan konsumen (pemohon PKB).

5. Mengetahui kriteria pelayanan mana yang pengaruhnya terhadap kepuasan konsumen paling dominan?

Berdasar uraian tersebut di atas, kerangka pikir yang digunakan dalam penelitan ini adalah: Tujuan penyelenggaraan Pengujian Kendaraan Bermotor yaitu untuk memberikan kepastian bahwa kendaraan bermotor yang dioperasikan di jalan telah memenuhi persyaratan teknis dan layakk jalan serta tidak mencemari lingkungan, terciptanya transportasi darat yang sesuai dengan kelayakan untuk berada dijalan dan juga agar pelanggan transportasi darat merasa aman, nyaman, cepat/lancar, dan tertib/teratur serta lebih percaya pada sarana transportasi yang digunakan, termasuk kelengkapan surat-surat kendaraan bermotor yang merupakan kewenangan dari Dinas Perhubungan. Sasaran penyelenggaraan Pengujian Berkala Kendaraan Bermotor ditujukan kepada kendaraan wajib uji yakni mobil penumpang umum, mobil bus, mobil barang, kereta tempelan dan kereta gandengan.

Pengujian kendaraan dilakukan oleh Penguji Kendaraan Bermotor, yaitu Pegawai Negeri Sipil yang diberi tugas, tanggung jawab, wewenang, dan hak secara penuh oleh pejabat yang berwenang untuk melakukan tugas pengujian kendaraan bermotor. Sebagai penguji kendaraan bermotor, maka pegawai ini harus memiliki Sertifikat Kompetensi dan Tanda Kualifikasi Teknis Penguji Kendaraan Bermotor. Pegawai dalam memberikan pelayanan harus memenuhi kriteria seperti yang tertuang dalam Surat Keputusan MENPAN No. 63/2003 tentang Pedoman Penyelenggaraan Umum yang pelayanannya meliputi: 1) prosedur pelayanan, 2) waktu pelayanan, 3) biaya pelayanan, 4) produk pelayanan, 5) sarana dan prasarana, serta 6) kompetensi dari petugas pemberi pelayanan. 
Dengan adanya pemenuhan standar pelayanan yang dimiliki pegawai tersebut maka organisasi yang dijalankannya juga dapat mencapai kinerja yang baik. Kinerja organisasi yang baik diharapkan dapat memberikan kepuasan kepada konsumen dalam pelayanannya. Dengan kinerja pegawai yang menunjang kinerja organisasi maka diharapkan dapat memenuhi kepuasan konsumen yang dapat diukur berdasarkan: (Zeithaml, Berry, dan Parasuraman dalam Yamit, 2005) 1) bukti fisik (tangibles) 2) keandalan (reliability), 3) responsif atau daya tangkap (responsiveness), 4) keyakinan (assurance), dan 5) empati (empathy). Kinerja organisasi dan kepuasan konsumen, dinilai oleh konsumen (pemohon PKB). Kerangka pikir tersebut disajikan sebagai berikut:

\begin{tabular}{|c|c|}
\hline $\begin{array}{l}\text { Kinerja Pegawai dalam Pelayanan, } \\
\text { kriteria: } \\
\text { (SK MENPAN No. 63/2003) } \\
\text { - Prosedur pelayanan } \\
\text { - Waktu pelayanan } \\
\text { - Biaya pelayanan } \\
\text { - Produk pelayanan } \\
\text { - Sarana dan prasarana pelayanan } \\
\text { - Kompetensi petugas pelayanan }\end{array}$ & $\begin{array}{l}\text { Kinerja Organisasi dalam Pelayanan, } \\
\text { kriteria: } \\
\text { (SK MENPAN No. 63/2003) } \\
\text { - Prosedur pelayanan } \\
\text { - Waktu pelayanan } \\
\text { - Biaya pelayanan } \\
\text { - Produk pelayanan } \\
\text { - Sarana dan prasarana pelayanan } \\
\text { - Kompetensi petugas pelayanan }\end{array}$ \\
\hline $\begin{array}{l}\text { Kinerja Organisasi } \\
\text { - Prosedur pelayanan } \\
\text { - Waktu pelayanan } \\
\text { - Biaya pelayanan } \\
\text { - Produk pelayanan } \\
\text { - Sarana dan prasarana pelayanan } \\
\text { - Kompetensi petugas pelayanan }\end{array}$ & $\begin{array}{l}\text { Kepuasan Konsumen } \\
\text { - Bukti fisik (tangibles) } \\
\text { - Keandalan (reliability) } \\
\text { - Responsif/daya tangkap } \\
\text { (responsiveness) } \\
\text { - Keyakinan (assurance) } \\
\text { - Empati (emphaty) }\end{array}$ \\
\hline
\end{tabular}

Berkenaan dengan kerangka pikir tersebut, maka hipotesis yang diajukan dalam penelitian ini adalah:

1. Tidak ada perbedaan kinerja pegawai dan kinerja organisasi dalam pelayanan.

2. Ada pengaruh kinerja organisasi (mencakup: Prosedur pelayanan, Waktu pelayanan, Biaya pelayanan, Produk pelayanan, Sarana dan prasarana pelayanan, serta Kompetensi petugas pelayanan) terhadap kepuasan konsumen.

\section{METODE PENELITIAN}

Penelitian dilakukan di UPTD Pengujian Kendaraan Bermotor (PKB) Dinas Perhubungan, Komunikasi, dan Informatika Kabupaten Sleman yang melakukan pelayanan terhadap masyarakat. Populasi dalam penelitian ini adalah semua PNS di UPTD PKB Dinas Perhubkominfo Kabupaten Sleman sebanyak 22 orang dan konsumen atau masyarakat pemohon PKB. Semua populasi petugas pelayanan PNS di UPTD PKB dijadikan responden atau disebut metode sensus (Sugiyono, 2010), sedangkan untuk masyarakat pemohon PKB diambil sampel sebanyak 50 orang dengan metode accidental sampling. Variabel yang digunakan dalam penelitian ini adalah:

1. Kinerja pegawai (PNS di UPTD PKB) dan kinerja organisasi (UPTD PKB)

2. Variabel bebas, kinerja organisasi (pelayan PKB), mencakup: prosedur pelayanan, waktu pelayanan, biaya pelayanan, produk pelayanan, sarana dan prasarana pelayanan, serta kompetensi petugas pelayanan, sedangkan variabel tergantung adalah kepuasan konsumen (masyarakat pemohon PKB). 
Data yang diperlukan dalam penelitian ini adalah data primer dari responden dan data sekunder dari buku-buku, majalah, koran maupun instansi yang ada kaitannya dengan penelitian. Metode pengumpulan data primer digunakan "Metode Angket," sedangkan metode pengukurannya dengan skala Likert, yaitu suatu skala yang digunakan untuk mengukur sikap, pendapat, persepsi dari seseorang tentang suatu fenomena sosial (Sugiyono, 2010). Jawaban dari setiap butir pernyataan disediakan lima alternatif jawaban dan penilaian untuk masing-masing alternatif jawaban dan diberikan bobot (skor): (a) Sangat Tidak Setuju (STS) skor 1, (b) Tidak Setuju (TS) skor 2, (c) Netral (N) skor 3, (d) Setuju (S) skor 4, dan (e) Sangat Setuju (SS) skor 5.

Indikator yang digunakan dalam masing-masing variabel adalah variabel Kinerja Pegawai dan variabel Kinerja Organisasi yang terdiri atas enam indikator dengan 18 butir pernyataan: (1) prosedur pelayanan 3 butir pernyataan, (2) waktu pelayanan 3 butir pernyataan, (3) biaya pelayanan 3 butir pernyataan, (4) produk pelayanan 3 butir pernyataan, (5) sarana dan prasarana pelayanan 3 butir pernyataan, (6) kompetensi petugas pelayanan 3 butir pernyataan. Variabel Kepuasan Konsumen terdiri atas 5 indikator dengan 19 butir pernyataan, yaitu: (1) bukti fisik (tangibles) 5 butir pernyataan, (2) keandalan (reliability) 4 butir pernyataan, (3) responsif/daya tangkap (responsiveness) 4 butir pernyataan, (4) keyakinan (assurance) 3 butir pernyataan, dan (5) empati (emphaty) 3 butir pernyataan.

Uji validitas dan uji reliabilitas terhadap semua pernyataan dari tiga variabel tersebut, telah dilakukan dengan 22 orang responden untuk variabel kinerja pegawai dan 30 orang responden untuk variabel kinerja organisasi dan kepuasan konsumen. Uji validitas dengan menghitung korelasi Pearson Product Moment (ryx). Hasil perhitungan semua butir pernyataan pada masing-masing variabel diperoleh nilai ryx-hitung lebih besar dibanding $\mathrm{r}$ tabel $(0,361)$, sehingga semua butir pernyataan dinyatakan valid. Uji reliabilitas dengan menghitung Alpha Cronbach, hasilnya menunjukkan bahwa nilai alpha ketiga variabel kinerja pegawai, kinerja organisasi, dan kepuasan konsumen di atas 0,6 sehingga semua variabel dinyatakan reliabel.

Metode analisis data yang digunakan dalam penelitian ini adalah analisis kualitatif dan analisis kuantitatif sebagai berikut:

1) Untuk menganalisis karakteristik responden digunakan analisis kualitatif Yaitu analisis yang hanya menggunakan paparan sederhana, baik menggunakan jumlah data maupun persentase dengan membuat distribusi frekuensi (Suharsimi Arikunto, 2010).

2) Untuk menganalisis tingkat pelayanan yang diberikan oleh pegawai (kinerja pegawai) dan oleh organisasi (kinerja organisas) dan tingkat kepuasan konsumen (pemohon PKB) digunakan Distribusi Frekuensi dan Rata-rata Hitung (Mean) . dengan interval 0,8 dan ada 5 kriteria yaitu sangat rendah, rendah, cukup, tinggi, sangat tinggi.

3) Untuk menganalisis tidak adanya perbedaan atau adanya kesamaan antara kinerja pegawai dan kinerja organisasi digunakan uji dua rata2 dengan uji-Z

4) Untuk menganalisis pengaruh kinerja organisasi (prosedur pelayanan: X1, waktu pelayanan: $X 2$, biaya pelayanan: $X 3$, produk pelayanan: $X 4$, sarana dan prasarana pelayanan: X5, serta kompetensi petugas pelayanan: X6) terhadap kepuasan konsumen digunakan analisis regresi berganda (Ghozali, 2008). Model persamaan regresi berganda sebagai berikut:

$$
\mathrm{Y}=\beta_{1} \mathrm{X}_{1}+\beta_{2} \mathrm{X}_{2}+\beta_{3} \mathrm{X}_{3}+\beta_{4} \mathrm{X}_{4}+\beta_{5} \mathrm{X}_{5}+\beta_{6} \mathrm{X}_{6}+\varepsilon \mathrm{i}
$$

Untuk menguji pengaruh kinerja organisasi (X1 hingga X6) terhadap kepuasan konsumen secara parsial digunakan uji-t, sedangkan uji serempak digunakan uji-F 
5) Untuk mengetahui variabel (X) mana yang pengaruhnya paling dominan terhadap variabel kepuasan konsumen (Y) dapat dilihat dari koefisien determinasi parsial terbesar.

\section{HASIL PENELITIAN DAN PEMBAHASAN}

Pengumpulan data dengan kuesioner dilakukan terhadap 22 responden pegawai UPDT PKB dan 50 responden konsumen PKB. Setelah dilakukan analisis, hasilnya sebagai berikut:

1. a. Dari 22 orang responden pegawai UPTD PKB terbanyak adalah: jenis kelamin lakilaki yaitu 20 orang $(90,9 \%)$, usia berkisar antara 31-40 tahun yaitu 35 orang (50\%), dan berpendidikan S1 yaitu 55 orang $(78,57 \%)$, dan masa kerja berkisar antara 11-15 tahun yaitu 27 orang $(38,57 \%)$.

b. Dari 50 orang responden konsumen pemohon PKB terbanyak adalah: jenis kelamin laki-laki yaitu semua responden 50 orang (100\%), usia berkisar antara 41-50 tahun yaitu 21 orang $(42 \%)$, berpendidikan SMA yaitu 31 orang $(62 \%)$, dan pekerjaan karyawan swasta 28 orang $(56 \%)$.

2. Tingkat pelayanan yang diberikan oleh pegawai atau kinerja pegawai, kinerja organisasi, dan tingkat kepuasan konsumen UPTD PKB Dinas Perhubkominfo Kabupaten Sleman dapat dijelaskan sebagai berikut:

a. Tingkat pelayanan yang diberikan oleh pegawai atau kinerja pegawai. Dari enam kriteria (MENPAN No. 63/2003) dan setiap kriteria terdiri atas tiga butir pernyataan. (1) Prosedur pelayanan. Sebagian besar responden pegawai rata-rata menyatakan "setuju (S) yaitu 51,52\% dan sangat setuju (SS) yaitu 48,48\%, bahwa pegawai memperhatikan prosedur pelayanan PKB. (2) Waktu pelayanan. Sebagian besar responden pegawai rata-rata menyatakan "setuju (S) yaitu 51,52\% dan sangat setuju (SS) yaitu $42,42 \%$, bahwa pegawai memperhatikan ketepatan waktu pelayanan. (3) Biaya pelayanan. Sebagian besar responden pegawai rata-rata menyatakan "setuju (S) yaitu $66,67 \%$ dan sangat setuju (SS) yaitu 33,33\%, bahwa pegawai memperhatikan ketetapan biaya pelayanan. (4) Produk pelayanan. Sebagian besar responden pegawai rata-rata menyatakan "setuju (S) yaitu $60,60 \%$ dan sangat setuju (SS) yaitu 37,88\%, bahwa pegawai memperhatikan kesesuaian produk pelayanan. (5) Sarana dan prasarana pelayanan. Sebagian besar responden pegawai rata-rata menyatakan "setuju (S) yaitu 51,52\% dan sangat setuju (SS) yaitu 48,48\% bahwa pegawai memperhatikan keberadaan sarana dan prasarana pelayanan. (6) kompetensi petugas pelayanan. Sebagian besar responden pegawai rata-rata menyatakan "sangat setuju (SS) yaitu 48,48\% dan setuju (S) yaitu 46,97\%, bahwa pegawai dalam melakukan PKB mempunyai kompetensi petugas pelayanan. Secara keseluruhan, berdasarkan enam kriteria tersebut, kinerja pegawai dalam menjalankan PKB memiliki nilai rata-rata skor (mean) sebesar 4,1189. Hasil inii menunjukkan berada dalam interval 3,41-4,20, sehingga masuk kriteria "tinggi."

b. Tingkat pelayanan yang diberikan oleh organisasi UPTD PKB/kinerja organisasi dinilai oleh konsumen pemohon PKB. Berdasarkan enam kriteria (MENPAN No. 63/2003) dan setiap kriteria terdiri atas tiga butir pernyataan. (1) Prosedur pelayanan. Sebagian besar responden konsumen rata-rata menyatakan "setuju (S) yaitu $56,67 \%$ dan sangat setuju (SS) yaitu $32 \%$, bahwa organisasi memperhatikan prosedur pelayanan PKB. (2) Waktu pelayanan. Sebagian besar responden konsumen rata-rata menyatakan "setuju (S) yaitu 68,67\% dan sangat setuju (SS) yaitu $26,67 \%$, bahwa organisasi memperhatikan ketepatan waktu pelayanan. (3) Biaya pelayanan. Sebagian besar responden konsumen rata-rata menyatakan "setuju 
(S) yaitu 57,33\% dan sangat setuju (SS) yaitu 32,67\%, bahwa organisasi memperhatikan ketetapan biaya pelayanan. (4) Produk pelayanan. Sebagian besar responden konsumen rata-rata menyatakan "setuju (S) yaitu 58,67\% dan sangat setuju (SS) yaitu 36,67\%, bahwa organisasi memperhatikan kesesuaian produk pelayanan. (5) Sarana dan prasarana pelayanan. Sebagian besar responden konsumen rata-rata menyatakan "setuju (S) yaitu 59,33\% dan sangat setuju (SS) yaitu 39,33\%, bahwa organisasi memperhatikan keberadaan sarana dan prasarana pelayanan. (6) Kompetensi petugas pelayanan. Sebagian besar responden konsumen rata-rata menyatakan "sangat setuju (SS) yaitu 57,33\% dan setuju (S) yaitu 42,67\%, bahwa organisasi dalam melakukan PKB mempunyai kompetensi petugas pelayanan. Secara keseluruhan, berdasarkan enam kriteria tersebut, kinerja organisasi dalam menjalankan PKB memiliki nilai rata-rata skor (mean) sebesar 4,0122. Kondisi ini berada dalam interval 3,41-4,20, sehingga masuk dalam kriteria "tinggi."

c. Tingkat kepuasan konsumen pemohon PKB dinilai berdasarkan lima indikator dengan 19 butir pernyataan: (1) Bukti fisik (tangibles) terdiri atas lima butir pernyataan. Sebagian besar responden konsumen rata-rata menyatakan "setuju" (S) yaitu $56,67 \%$ dan sangat setuju (SS) yaitu $32 \%$, bahwa organisasi memperhatikan penampilan fisik dalam memberikan pelayanan. (2) Keandalan (reliability) terdiri atas empat butir pernyataan. Sebagian besar responden konsumen rata-rata menyatakan "setuju" (S) yaitu 66,5\% dan sangat setuju (SS) yaitu 33,5\%, bahwa organisasi memperhatikan keandalan dalam memberikan pelayanan. (3) Responsif/ daya tangkap (responsiveness) terdiri atas empat butir pernyataan. Sebagian besar responden konsumen rata-rata menyatakan "setuju" (S) yaitu 53\% dan sangat setuju (SS) yaitu 37\%, bahwa organisasi responsif dalam memberikan pelayanan. (4) Keyakinan (assurance) terdiri atas tiga butir pernyataan. Sebagian besar responden konsumen rata-rata menyatakan "setuju" (S) yaitu 56,67\% dan sangat setuju (SS) yaitu 34\%, bahwa organisasi dapat memberikan keyakinan dalam pelayanan. (5) empati (emphaty) terdiri atas tiga butir pernyataan. Sebagian besar responden konsumen rata-rata menyatakan "setuju" (S) yaitu 48,67\% dan sangat setuju (SS) yaitu $42,67 \%$, bahwa organisasi daspat memberikan empati dalam pelayanan. Secara keseluruhan, berdasarkan lima indikator tersebut, tingkat kepuasan konsumen pemohon PKB memiliki nilai rata-rata skor (mean) sebesar 4,2642 Kondisi ini berada dalam interval 4,21-5,00, sehingga masuk dalam kriteria "sangat tinggi."

3. Untuk menganalisis tidak adanya perbedaan tingkat pelayanan/kinerja pegawai yang dinilai intern organisasi (UPTD PKB) dan tingkat pelayanan/kineja organisasi yang dinilai oleh konsumen (pemohon PKB), sesuai kriteria SK MENPAN No. 63/2003, yang berarti kinerja pegawai akan menunjang kinerja organisasi, digunakan uji dua rata-rata dengan uji-Z. Perhitungan dari 22 orang responden pegawai dan 50 orang responden konsumen perhitungan diperoleh nilai Z-hitung $=0,1021$ dan probabilitas $=$ 0,3186 . Karena nilai Z-hitung $<$ Z-tabel atau 0,1021 < 1,96 dan nilai probabilitas $0,3186>0,05$ maka dapat disimpulkan tidak ada perbedaan kinerja pegawai dengan kinerja organisasi. Dengan demikian, kesimpulannya adalah kinerja pegawai akan menunjang kinerja organisasi.

4. Pengaruh tingkat pelayanan/kinerja organisasi (sesuai kiriteria SK MENPAN No. $63 / 2003$ meliputi prosedur pelayanan, waktu pelayanan, biaya pelayanan, produk pelayanan, sarana dan prasarana, serta kompetensi petugas pemberi pelayanan) terhadap kepuasan konsumen (pemohon PKB) 
Berdasar hasil analisis dengan program SPSS (Ghozali, 2011) diperoleh hasil sebagai berikut:

a. Sebelum dilakukan analisis regresi berganda telah dilakukan uji asumsi dasar dan asumsi klasik. Uji asumsi dasar meliputi uji linearitas dan uji normalitas. Uji linearitas untuk hubungan variabel kinerja organisasi (X1 sampai dengan X6) dengan variabel kepuasan konsumen, hasilnya dinyatakan signifikan atau ada hubungan linier. Dan hasil uji normalitas menunjukkan bahwa semua variabel yang digunakan dalam penelitian ini memiliki random data yang berdistribusi normal. Sedang untuk uji asumsi klasik karena datanya bersifat "cross section" maka hanya meliputi uji heteroskedastisitas yang kesimpulannya tidak terjadi heteroskedastisitas dan uji multikolinearitas yang kesimpulannya model regresi tidak terjadi masalah mutikolinearitas atau tidak terjadi korelasi di antara variabel-variabel bebas. Dengan demikian analisis regresi berganda telah memenuhi persyaratan untuk dilanjutkan. Hasil perhitungan analisis regresi berganda dengan SPSS sebagai berikut:

Tabel 1. Hasil Perhitungan Koefisien Regresi dan Uji-t

\begin{tabular}{|c|c|c|c|c|c|c|}
\hline \multirow[t]{2}{*}{ Model } & Unstandardized & Coefficients & $\begin{array}{l}\text { Standardized } \\
\text { Coefficients }\end{array}$ & \multirow[t]{2}{*}{$\mathbf{t}$} & \multirow[t]{2}{*}{ Sig. } & Correlation \\
\hline & B & Std Error & Beta & & & Partial \\
\hline (CONSTANT) & .123 & .230 & & .536 & .595 & \\
\hline $\begin{array}{l}\mathrm{X}_{1}: \text { prosedur } \\
\text { pelayanan }\end{array}$ & .198 & .075 & .224 & 2.638 & ,012 & .373 \\
\hline $\begin{array}{l}\mathrm{X}_{2}: \text { waktu } \\
\text { pelayanan }\end{array}$ & .157 & .078 & .116 & 2.017 & .049 & .294 \\
\hline $\begin{array}{l}\mathrm{X}_{3} \text { : biaya } \\
\text { pelayanan }\end{array}$ & .198 & .060 & .199 & 3.326 & .002 & .345 \\
\hline $\begin{array}{l}\mathrm{X}_{4}: \text { produk } \\
\quad \text { Pelayanan }\end{array}$ & .215 & .096 & .236 & 2.240 & .030 & .323 \\
\hline $\begin{array}{c}\mathrm{X}_{5}: \text { sarana dan } \\
\text { Prasarana } \\
\text { Pelayanan }\end{array}$ & .154 & .047 & .198 & 3.306 & .002 & .450 \\
\hline $\begin{array}{c}\mathrm{X}_{6}: \text { kompetensi } \\
\text { Petugas } \\
\text { Pelayanan }\end{array}$ & .119 & .048 & .163 & 2.490 & .017 & .355 \\
\hline
\end{tabular}

Dependent Variable: Y: Kepuasan Konsumen

Sumber: olah data dengan SPSS, 2017.

Tabel 2. Hasil Perhitungan Uji-F

\begin{tabular}{|c|c|c|c|c|c|}
\hline Model & Sum of Squares & Df & Mean Square & $\mathbf{F}$ & Sig \\
\hline Regression & 3.511 & 6 & .585 & 77.920 &, $000^{\mathrm{b}}$ \\
\hline Residual & 0.323 & 43 & .008 & & \\
\hline Total & 3.834 & 49 & & & \\
\hline
\end{tabular}

Sumber: olah data dengan SPSS, 2017.

b. Persamaan regresi berganda:

$$
Y=0,123+0,198 X_{1}+0,157 X_{2}+0,198 X_{3}+0,215 X_{4}+0,154 X_{5}+0,119 X_{6}
$$

$\mathrm{Y}$ : variabel kepuasan konsumen, $\mathrm{X}_{1}$ : prosedur pelayanan, $\mathrm{X}_{2}$ : waktu pelayanan, $\mathrm{X}_{3}$ : biaya pelayanan, $\mathrm{X}_{4}$ : produk pelayanan, $\mathrm{X}_{5}$ : sarana dan prasarana pelayanan, $\mathrm{X}_{6}$ : kompetensi petugas pelayanan.

Semua koefisien regresi untuk semua variabel bertanda positif. Hal ini menggambarkan bahwa jika pelayanan atau kinerja organisasi (meliputi prosedur pelayanan, waktu pelayanan, kepastian biaya pelayanan, produk pelayanan, sarana 
prasarana pelayanan, dan kompetensi petugas pelayanan) ditingkatkan, maka kepuasan konsumen pemohon PKB juga akan meningkat.

Hasil uji hipotesis terhadap koefisien regresi secara bersama-sama (Uji-F) diperoleh nilai F-hitung $=77,92$ dengan tingkat signifikasi (nilai probabilitas) $=0,00$ dan posisinya di bawah nilai 0,05 . Dengan demikian, terbukti bahwa semua variabel kinerja organisasi (X1 s/d X6) secara bersama-sama dapat meningkatkan kepuasan konsumen pemohon PKB secara signifikan. Hal ini didukung juga dengan nilai koefisien korelasi berganda $\mathrm{R}=0,916$ (mendekati nilai 1) yang berarti korelasinya sangat kuat. Nilai koefisien determinasi atau $\mathrm{R}^{2}=0,904$ atau $90,4 \%$ yang berarti variasi peningkatan kepuasan konsumen pemohon PKB sebanyak 90,4\% dapat dijelaskan oleh peningkatan variabel kinerja organisasi (X1 s/d X6) secara bersamasama, sedangkan sisanya 9,6\% dijelaskan oleh variabel lain di luar variabel-variabel yang digunakan dalam penelitian ini.

Hasil uji hipotesis terhadap koefisien regresi secara parsial (Uji-t) diperoleh nilai thitung masing-masing variabel sebagai berikut: t-hitung $X_{1}$ (prosedur pelayanan) $=2,638$ dengan tingkat signifikasi (nilai probabilitas) $=0,012$; t-hitung $\mathrm{X}_{2}$ (waktu pelayanan $)=2,017$ dengan tingkat signifikasi (nilai probabilitas) $=0,049$; t-hitung $\mathrm{X}_{3}$ (biaya pelayanan) $=3,326$ dengan tingkat signifikasi (nilai probabilitas) $=0,02$ : thitung $\mathrm{X}_{4}$ (produk pelayanan) dengan tingkat signifikasi (nilai probabilitas) $=0,03$; $\mathrm{t}$ hitung $\mathrm{X}_{5}$ (sarana dan prasarana pelayanan) dengan tingkat signifikasi (nilai probabilitas) $=0,02$ dan t-hitung $\mathrm{X}_{6}$ (kompetensi petugas pelayanan) dengan tingkat signifikasi (nilai probabilitas) $=0,017$. Nilai probabilitas semua variabel posisinya berada di bawah nilai 0,05 . Dengan demikian terbukti bahwa semua variabel kinerja organisasi (X1 sampai dengan X6) secara parsial dapat meningkatkan kepuasan konsumen pemohon PKB secara signifikan.

5. Nilai koefisien determinasi parsial $\left(\mathrm{r}^{2}\right)$ variabel kinerja organisasi sebagai berikut: $r^{2} \times 1$ (prosedur pelayanan $)=(0,373)^{2}=0,139=13,9 \% ; r^{2} \times 2$ (waktu pelayanan $)=(0,294)^{2}$ $=0,086=8,6 \% ; \quad r^{2} \times 3 \quad$ (biaya pelayanan $)=(0,352)^{2}=0,124=12,4 \% ; \quad r^{2} \times 4 \quad$ (produk pelayanan $)=(0,323)^{2}=0,104=10,4 \% ; r^{2} \times 5$ (sarana dan prasarana pelayanan $)=(0,450)^{2}$ $=0,2025=20,25 \% ; r^{2} \times 6$ (kompetensi petugas pelayanan $)=(0,355)^{2}=0,1260=12,6 \%$. Jika diurutkan dari nilai $\mathrm{r}^{2}$ tertinggi adalah: 1) sarana dan prasarana pelayanan $\left(\mathrm{r}^{2} \mathrm{X}=20,25 \%\right)$; 2) prosedur pelayanan $\left.\left(\mathrm{r}^{2} \mathrm{X1}=13,9 \%\right) ; 3\right)$ kompetensi petugas pelayanan $\left(\mathrm{r}^{2} \mathrm{x}_{6}=12,6 \%\right)$; 4) biaya pelayanan $\left(\mathrm{r}^{2} \mathrm{X3}=12,4 \%\right)$; $)$ produk pelayanan $\left.\left(r^{2} \times 4=10,4 \%\right) ; 6\right) r^{2} \times 2$ waktu pelayanan $\left(r^{2} x_{2}=8,6 \%\right)$. Dengan demikian, variabel sarana dan prasarana pelayanan merupakan variabel yang paling dominan pengaruhnya untuk meningkatkan kepuasan konsumen pemohon PKB.

\section{KESIMPULAN DAN SARAN}

Dari hasil penelitian dan pembahasan dapat disimpulkan:

1. a. Dari responden 22 orang pegawai UPTD PKB terbanyak adalah: jenis kelamin lakilaki yaitu 20 orang $(90,9 \%)$, usia berkisar antara 31-40 tahun yaitu 35 orang (50\%), dan berpendidikan S1 yaitu 55 orang (78,57\%), dan masa kerja berkisar antara 11-15 tahun yaitu 27 orang $(38,57 \%)$.

b. Dari responden 50 konsumen pemohon PKB terbanyak adalah: jenis kelamin lakilaki yaitu semua responden 50 orang (100\%), usia berkisar antara 41-50 tahun yaitu 
21 orang (42\%), berpendidikan SMA yaitu 31 orang (62\%), dan pekerjaan karyawan swasta 28 orang $(56 \%)$.

2. Tingkat pelayanan yang diberikan oleh pegawai/kinerja pegawai, kinerja organisasi dan tingkat kepuasan konsumen UPTD PKB Dinas Perhubkominfo Kabupaten Sleman dapat di jelaskan sebagai berikut:

a. Tingkat pelayanan yang diberikan oleh pegawai/kinerja pegawai maupun kinerja organisasi, ada 6 kriteria (MENPAN No. 63/2003) dan setiap kriteria ada 3 item pernyataan. 1) Prosedur pelayanan, 2) Waktu pelayanan 3) Biaya pelayanan 4) Produk pelayanan. 5) Sarana dan prasarana pelayanan. 6) kompetensi petugas pelayanan. Sebagian besar responden menyatakan "S" dan "SS" bahwa pegawai sudah menjalankan pelayanan sesuai dengan kriteria yang ditetapkan. Secara keseluruhan, berdasar 6 kriteria tersebut, kinerja pegawai maupun kinerja organisasi UPTD PKB dalam menjalankan pelayanan masuk kriteria "tinggi"

b. Tingkat kepuasan konsumen pemohon PKB dinilai berdasar 5 indikator dengan 19 item pernyataan:1) Bukti fisik (tangibles) 2) Keandalan (reliability) 3) Responsif/daya tangkap (responsiveness), 4) Keyakinan (assurance), dan 5) empati (emphaty) Sebagian besar responden konsumen rata-rata menyatakan " $S$ " dan "SS" bahwa organisasi sudah memberikan pelayanan sesuai 5 indikator tersebut. Secara keseluruhan, tingkat kepuasan konsumen pemohon PKB masuk kriteria "sangat tinggi"

3. Berdasarkan uji dua rata-rata dengan uji-Z. Perhitungan dari 22 orang responden pegawai dan 50 orang responden konsumen pemohon PKP dapat disimpulkan tidak ada perbedaan kinerja pegawai dengan kinerja organisasi. Dengan demikian, dapat disimpulkan bahwa kinerja pegawai akan menunjang kinerja organisasi.

4. Pengaruh tingkat pelayanan/kinerja organisasi (sesuai kiriteria SK MENPAN No.63/2003 meliputi prosedur pelayanan, waktu pelayanan, biaya pelayanan, produk pelayanan, sarana dan prasarana, serta kompetensi petugas pemberi pelayanan) terhadap kepuasan konsumen (pemohon PKB), diperoleh hasil bahwa secara bersamasama (Uji-F) dan secara parsial (uji-t) berpengaruh terhadap peningkatan kepuasan konsumen secara dsigniufikan. Hal ini juga didukung dengan nilai koefisien detrerminasi atau $\mathrm{R}^{2}$ yang tinggi.

5. Berdasar koefisien determinasi parsial $\left(\mathrm{r}^{2}\right)$ dalam variabel kinerja organisasi, variabel sarana dan prasarana pelayanan mempunyai nilai $\mathrm{r}^{2}$ tertinggi, sehingga merupakan variabel yang paling dominan pengaruhnya untuk meningkatkan kepuasan konsumen pemohon PKB.

Saran yang diajukan adalah upaya meningkatkan kinerja pegawai guna menunjang kinerja organisasi, dalam upaya meningkatkan kepuasan konsumen PKB sebaiknya memperhatikan kiriteria SK MENPAN No. 63/2003 khususnya kriteria sarana dan prasarana (yang pengaruhnya paling dominan) tanpa meninggalkan kriteria yang lain. Sarana prasarana semakin lama akan semakin usang, maka perlu adanya pemeliharaan dan peningkatan secara kontinyu. Di samping itu, jika ada pegawai yang pensiun, pegawai baru yang direkrut di UPTD PKB harus segera dididik lebih lanjut agar segera memiliki Sertifikat Kompetensi dan Tanda Kualifikasi Teknis Penguji Kendaraan Bermotor karena hal ini akan menunjang kinerja organisasi yang akan memberikan kepuasan konsumen pemohon PKB. 


\section{DAFTAR REFERENSI}

Arikunto, S. (2010). Prosedur Penelitian Suatu Pendekatan Praktek. Jakarta: Rineka Cipta.

Ghozali, I. (2011). Aplikasi Analisis Multivariate Dengan Program IBM. SPSS 19. Semarang: Universitas Diponegoro.

Hasibuan, M.S.P. (2012). Manajemen Sumber Daya Manusia. Jakarta: Bumi Aksara.

Kotler, P. \& Keller, K.L. (2009). Manajemen Pemasaran. Terjemahan Bob Sabran, MM. Jakarta: Penerbit Erlangga.

Mangkunegara, A.P. (2005). Evaluasi Kinerja SDM. Bandung: PT. Remaja Rosdakarya.

Menteri Pendayagunaan Aparatur Negara. (2003). Keputusan MENPAN No. 63/2003 tentang Pedoman Penyelenggaraan Umum. Jakarta.

Moenir. (2002). Manajemen Pelayanan Umum di Indonesia. Jakarta: Bumi Aksara.

Republik Indonesia. (2003). Undang-Undang RI Nomor 13 Tahun 2003 Tentang Ketenagakerjaan, Jakarta.

Republik Indonesia. (2009). Undang-Undang RI Nomor 25 Tahun 2009 Tentang Pelayanan Publik. Jakarta.

Sugiyono. (2010). Metode Penelitian Bisnis. Bandung: Alfabeta.

Yamit, Z. (2005). Manajemen Kualitas Produk dan Jasa. Yogyakarta: Ekomisis.

Zeithaml, V.A. \& Bitner, M.J. (2000). Service Marketing. Singapore: Mc.Graw-Hill, Inc. 